\title{
Impact of coal mining on water quality of three artificial lakes in Morozini River Basin (Treviso, Santa Catarina State, Brazil)
}

Impacto da atividade de mineração na qualidade da água de três lagos artificiais da bacia do rio Morozini (Treviso, Estado de Santa Catarina, Brasil)

Viviane Moschini-Carlos ${ }^{1}$, Marcelo Luiz Martins Pompêo²,

Felipe de Lucia Lobo ${ }^{3}$ and Sergio Tadeu Meirelles ${ }^{2}$

${ }^{1}$ Universidade Estadual Paulista - UNESP,

Av. 3 de março, 511, Alto da Boa Vista, CEP 18087-180, Sorocaba, SP, Brazil

e-mail: viviane@sorocaba.unesp.br

${ }^{2}$ Departamento de Ecologia, Instituto de Biociências, Universidade de São Paulo - USP,

Rua Matão, 321, travessa 14, Cidade Universitária, CEP 05508-900, São Paulo, SP, Brazil e-mail: mpompeo@ib.usp.br; stmeirel@ib.usp.br

${ }^{3}$ Instituto Nacional de Pesquisas Espaciais - INPE,

Av. dos Astronautas, 1758, Jd. Granja, CEP 12227-010, São José dos Campos, SP, Brazil e-mail: lobo@dsr.inpe.br

\begin{abstract}
Aim: To assess water quality of three lakes located in an abandoned coal mining area, in the Morozini River basin (Treviso, Santa Catarina State, Brazil). Methods: The study sites were three lakes mining pits flooded after deactivation, near the drainage basin of the Morozini River (Treviso City, Santa Catarina State, Brazil). Samplings were carried out in profile in the limnetic region during two seasons (Summer in February and Winter in July). Results: In general, the three lakes showed high concentrations of $\mathrm{SO}_{4}^{-2}, \mathrm{Mg}, \mathrm{Fe}, \mathrm{Al}, \mathrm{Ca}, \mathrm{Ba}, \mathrm{Si}, \mathrm{Zn}, \mathrm{Ni}, \mathrm{Na}, \mathrm{K}, \mathrm{Sr}, \mathrm{B}, \mathrm{Cd}, \mathrm{Cr}, \mathrm{Pb}$ and $\mathrm{Cu}$. Conclusions: Coal mining activity and waste disposal practices adopted by the mining companies in the Morozini River basin have drastically affected the water quality of the examined lakes and made them inappropriate for diverse human uses, such as leisure, swimming and fishing.
\end{abstract}

Keywords: CONAMA, metals, water quality, acidification.

Resumo: Objetivo: Avaliar a qualidade da água de três lagos presentes em uma área abandonada de mineração de carvão. Métodos: Foram amostrados em perfil três lagos presentes na bacia de drenagem do rio Morozini (Treviso, Santa Catarina, Brasil), com coletas em duas épocas do ano (fevereiro - verão e julho - inverno). Resultados: De maneira geral, os três lagos estudados apresentaram elevadas concentraçóes de $\mathrm{SO}_{4}^{-2}, \mathrm{Mg}$, $\mathrm{Fe}, \mathrm{Al}, \mathrm{Ca}, \mathrm{Ba}, \mathrm{Si}, \mathrm{Zn}, \mathrm{Ni}, \mathrm{Na}, \mathrm{K}, \mathrm{Sr}, \mathrm{B}, \mathrm{Cd}, \mathrm{Cr}, \mathrm{Pb}$ e Cu. Conclusóes: Esta pesquisa sugere que a atividade de mineraçáo e a prática de disposiçấo de rejeitos adotada pelas companhias de mineração afetaram drasticamente a qualidade da água dos lagos estudados, tornando-os inapropriados a diversos usos humanos, tais como lazer, pesca e natação.

Palavras-chave: CONAMA, metais, qualidade da água, acidificação.

\section{Introduction}

The impact of coal mining activity on the environment is of great concern, especially due to acidification of surface water bodies. Hence, mining requires complex planning that takes into account the specificity of techniques and characteristics of the affected environment (Kopezinski, 2000).

Currently, thermal energy is responsible for $5 \%$ of energy matrix in Brazil. However, the government aims to increase this ratio to $15 \%$ by 2015 . Rio Grande do Sul and Santa Catarina states account for $99 \%$ of known coal reserves, approximately 32 billion tons. Coal found in these states is of low quality: low calorific value and high ash (47 to $58 \%$ ) and sulfur (1 to 4.7\%) contents (JICA, 1995).

The main activities of coal mining (exploration, development, extraction, concentration, processing, refinement and deactivation) have a variety of impacts, which include soil damage, air pollution and water contamination (McAllister and Milioli, 2000). Areas that have been explored but not rehabilitated are a source of water pollution. This is mainly because of acid mine drainage (AMD), due to pyrite oxidation $\left(\mathrm{FeS}_{2}\right)$. When pyrite is in contact with oxygen and water, highly concentrated 
sulfuric acid is produced which solves metals (Rose and Cravotta, 1998; Asta et al., 2008).

The main objective of this work was to assess the water quality of three lakes situated in an abandoned coal mining area, submitted to anthropogenic impacts. It is expected that these lakes have strong use restriction, according to the Brazilian water quality regulation (CONAMA no 357/2005).

\section{Study Area}

The study region, is located in the south region of Santa Catarina State (Brazil), and has an area of $9,049 \mathrm{~km}^{2}, 9.8 \%$ of the total area of the state (Figure 1); it has 39 towns and a population of more than 800,000 inhabitants. The studied lakes are located in the Morozini River micro basin, near the Treviso city. Morozini River micro basin is a tributary of the Mãe Luzia River and is located in a 4,200 $\mathrm{m}$ (large axis) by 3,400 $\mathrm{m}$ (small axis) valley, with a topographical gradient of about $320 \mathrm{~m}$.

The Companhia Siderúrgica Nacional (CSN), established in the 1950s, is a company that explored and processed coal in the region. In the 1960s, coal mining was intensified closer to Treviso and became one of the most important economic activities. However, mining adversely affected other economic activities and also had social and environmental consequences causing a high level of pollution and reducing the water quality (Milioli, 1999).
Open-pit mining in this region began in 1982 and the resulting deposits have high sulfate concentration that reduces the $\mathrm{pH}$ in shallow lakes. The course of the Morozini River was modified many times due to surface coal mining, and, as final conformation, the river water flows through the mining pits that were dug by a Marion dragline. The pyrite waste was used to make gravel access roads to the mines. Many lakes near coalmines were used as dumps for the mining waste. Lakes have been formed in this region by the flow of underground and surface water into the mining pits (Waterloo, 2002). In the study area, at present, there is no more coal exploration and the lakes studied do not receive mining waste.

Climate type is wet subtropical with hot summer (Cfa - Köppen's classification). Mean annual temperature is $19{ }^{\circ} \mathrm{C}$ and total precipitation haste is $1600 \mathrm{~mm}$, distributed along the whole year, without well defined dry season. Mean monthly temperature varies from $15{ }^{\circ} \mathrm{C}$ in the winter to $24^{\circ} \mathrm{C}$ in summer, with possible incident of frost (Sônego et al., 2011). According to these authors, from March to September, there is predominance of hot air mass and moisture, causing strong heating during the days and formation of convective clouds. During the winter months, there is predominance of cold and dry polar air mass. For the series of 10 years (Figure 2), one can observe marked annual pattern of temperature, with lower values from

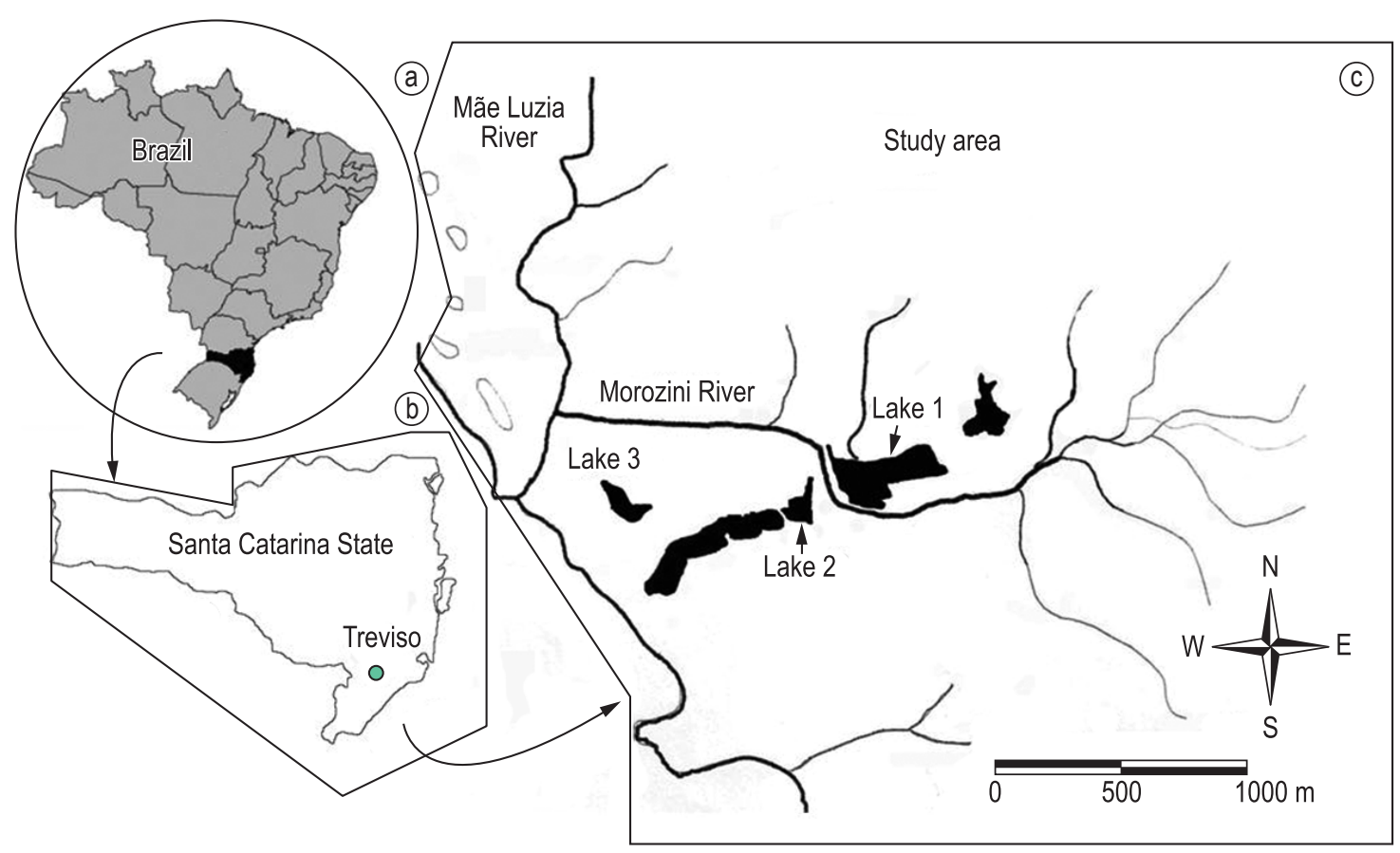

Figure 1. Study area (c) in Santa Catarina State (b), Brazil (a) and lakes studied (Lakes 1, 2 and 3). 
May to October. In 2003, when this research was developed, the total precipitation was $1509.8 \mathrm{~mm}$; annual mean minimum temperature was $15.4^{\circ} \mathrm{C}$ and annual mean maximum temperature of $20.0^{\circ} \mathrm{C}$.

\section{Material and Methods}

The study sites consisted of 3 lakes, mining pits flooded after deactivation, near the drainage basin of the Morozini River (Treviso, Santa Catarina State, Brazil) (Figure 1). Samplings were carried out considering a profile through the limnetic region in two seasons (summer, the month of February, and winter, the month of July, 2003).

Physical and chemical variables of the water were analyzed (Table 1). To analyze the total and dissolved nutrients concentration, water samples were collected and filtered in situ through a Whatman GF/C $47 \mathrm{~mm}$ membrane. The filtered water was acidified with $\mathrm{HNO}_{3}(1 \mathrm{~mL})$ and maintained in polythene vials protected from light until analysis.

Principal components analysis (PCA) was carried out to identify possible relationships among lakes, depth and season. The analysis was based on a product-moment matrix obtained from a rangestandardized matrix (Legendre and Legendre, 2003). The physical and chemical variables selected for the PCA were temperature $(\mathrm{t})$, total solids (TS), calcium $(\mathrm{Ca})$, aluminum $(\mathrm{Al})$, silicon $(\mathrm{Si})$, iron $(\mathrm{Fe})$, zinc $(\mathrm{Zn})$, nickel $(\mathrm{Ni}), \mathrm{pH}$, electric conductivity (EC) and dissolved oxygen (DO).

\section{Results}

Water from Lakes 1 and 2 were micro stratified during summer, and temperatures ranged from 27.2 to $31.1^{\circ} \mathrm{C}$. Water column of Lake 3 was relatively homogeneous in the summer, with temperature
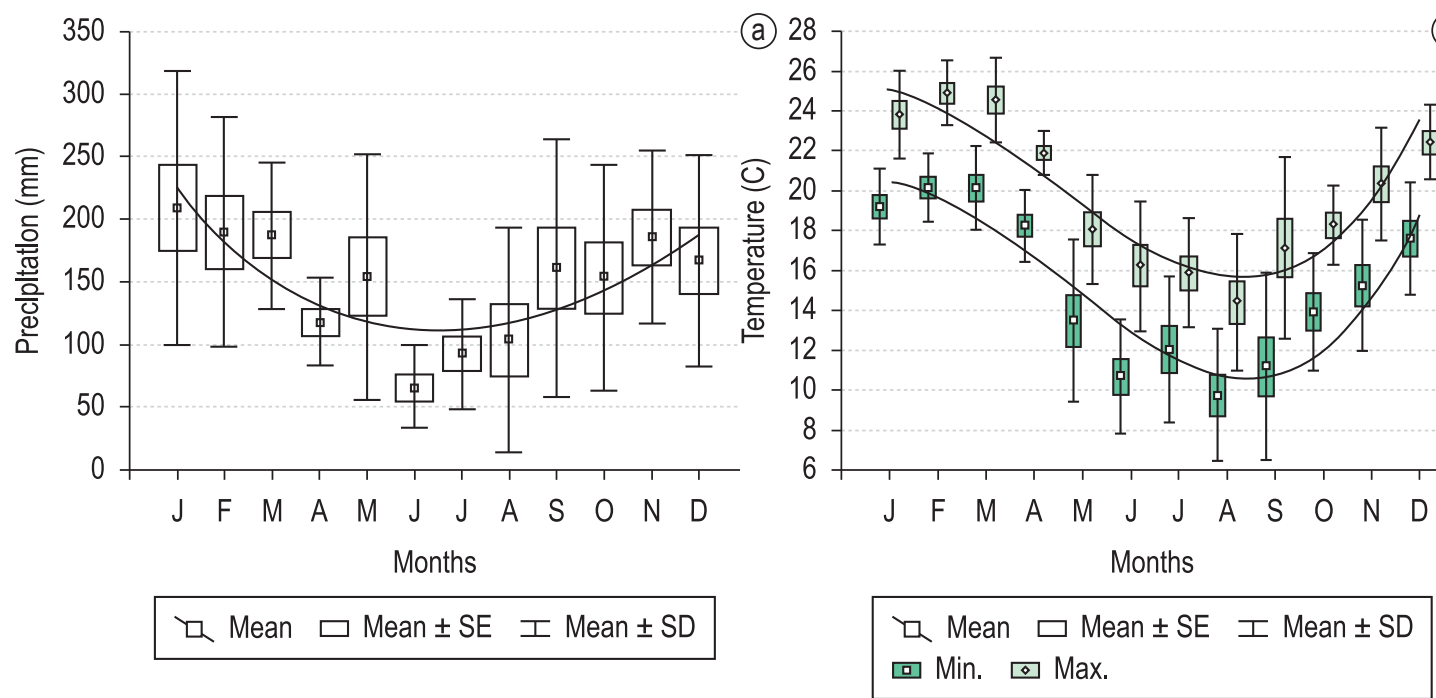

Figure 2. Precipitation (a) (mean total monthly) and temperature (b) (mean minimum and mean maximum for month), for 10 years (2001 to 2010), according Epagri/Ciram/Inmet (Urussanga Station, Santa Catarina State, Brazil, longitude: $49^{\circ} 18^{\prime} 53^{\prime \prime}$; latitude: $27^{\circ} 31^{\prime} 55^{\prime \prime}$ ). Tendency curve is a polynomial cubic function.

Table 1. Physical and chemical variables analyzed, units, methods and references.

\begin{tabular}{|c|c|c|c|}
\hline Variable & Unit & Method & Reference \\
\hline Water temperature & ${ }^{\circ} \mathrm{C}$ & Horiba U 10 & \\
\hline $\mathrm{pH}$ & & Gehaka PG 1400 & \\
\hline Dissolved oxygen (DO) & $m g \cdot L^{-1}$ & Winkler & Golterman et al. (1978) \\
\hline Electric conductivity (EC) & $\mu \mathrm{S} . \mathrm{cm}^{-1}$ & Hanna HI 9033 & \\
\hline Euphotic zone & $\mathrm{m}$ & Secchi Dish & \\
\hline Orthophosphate $\left(\mathrm{P}-\mathrm{PO}_{4}\right)$ & $\mu g \cdot L^{-1}$ & Spectrophotometric / Shimadzu UV 100001 & $\begin{array}{c}\text { Strickland and Parsons } \\
\text { (1960) }\end{array}$ \\
\hline Silicate $\left(\mathrm{S}-\mathrm{SIO}_{2}\right)$ & $\mathrm{mg} \cdot \mathrm{L}^{-1}$ & Spectrophotometric / Shimadzu UV 100001 & Goltermam et al. (1978) \\
\hline Total solids & $m g \cdot L^{-1}$ & Gravimetric & APHA (1985) \\
\hline $\begin{array}{l}\mathrm{P}, \mathrm{SO}_{4}^{-2}, \mathrm{Mg}, \mathrm{Fe}, \mathrm{Al}, \mathrm{Ca}, \mathrm{Ba}, \mathrm{Si} \\
\mathrm{Zn}, \mathrm{Ni}, \mathrm{Na}, \mathrm{K}, \mathrm{Sr}, \mathrm{B}, \mathrm{Cd}, \mathrm{Cr}, \mathrm{Pb}, \mathrm{Cu}\end{array}$ & $m g \cdot L^{-1}$ & $\begin{array}{l}\text { Atomic emission spectrometry with induced } \\
\text { coupled plasma (ICP-AES) }\end{array}$ & APHA (1985) \\
\hline
\end{tabular}


ranging from 24.5 and $31.1^{\circ} \mathrm{C}$. In the winter, none of the lakes was stratified, and temperatures were around $19^{\circ} \mathrm{C}$ (Figure 3a).

In Lake 2, $\mathrm{pH}$ increased with depth and values were 5.1 at the surface and 6.2 at the bottom, while the highest $\mathrm{pH}$ value was found at the surface (6.9) and at the bottom was 6.4 in the winter. The $\mathrm{pH}$ value for Lake 3 was approximately 3 (Figure $3 b$ ). Lake 1 showed a $\mathrm{pH}$ ranging from 7.3 (epilimnion) to 5.7 (hypolimnion) in the summer and from 6.3 (surface) to 7.4 (bottom) in the winter.

EC values were high $\left(700\right.$ to $\left.900 \mu \mathrm{S} . \mathrm{cm}^{-1}\right)$ in Lakes 1 and 2 in both periods and tended to increase from epilimnion downwards to hypolimnion in the summer but were relatively homogeneous in winter (Figure 3c). Lower EC values (about $300 \mu \mathrm{S} . \mathrm{cm}^{-1}$ ) were measured in Lake 3 in both periods.

In the summer, there was a decrease of DO from epilimnion (Lake 1, $7.23 \mathrm{mg} . \mathrm{L}^{-1}$ and Lake 2,
$6.75 \mathrm{mg} . \mathrm{L}^{-1}$ ) to hypolimnion (Lake 1, $1.01 \mathrm{mg} . \mathrm{L}^{-1}$ and Lake 2, $\left.3.72 \mathrm{mg} . \mathrm{L}^{-1}\right)$. A different pattern was observed in winter, when an orthograde profile was found with DO values greater than $6 \mathrm{mg} . \mathrm{L}^{-1}$ (Figure 3d). Lakes 1 and 2 showed higher TS concentrations (982.5 to $1161.5 \mathrm{mg} . \mathrm{L}^{-1}$ ) than Lake 3 (mean 230.6 mg.L $\mathrm{L}^{-1}$ ) (Figure 3e). Most part of TS was in the dissolved form (Table 2).

$\mathrm{SO}_{4}^{-2}, \mathrm{Ca}, \mathrm{Mg}$ and $\mathrm{K}$ concentrations were higher in Lakes 1 and 2 than in Lake 3. $\mathrm{SO}_{4}^{-2}$ concentration ranged from 505 to $676 \mathrm{mg} . \mathrm{L}^{-1}$ in Lakes 1 and 2, and from 93 to $111 \mathrm{mg} . \mathrm{L}^{-1}$ in Lake 3 (Figure 4a). Values for Ca concentration ranged from 177 to $213 \mathrm{mg} . \mathrm{L}^{-1}$ in Lakes 1 and 2, and from 5.9 to 8.7 mg. $\mathrm{L}^{-1}$ in Lake 3 (Figure $4 \mathrm{~b}$ ). $\mathrm{Mg}$ concentration ranged from 28 to $34 \mathrm{mg} . \mathrm{L}^{-1}$ in Lakes 1 and 2, and from 2.4 to $3.4 \mathrm{mg} . \mathrm{L}^{-1}$ in Lake 3 (Figure 4c). In Lakes 1 and 2, $\mathrm{Na}$ and $\mathrm{K}$ concentrations ranged from 5.6 to $6.1 \mathrm{mg} . \mathrm{L}^{-1}$ and 3.5 to $4.2 \mathrm{mg} . \mathrm{L}^{-1}$, in

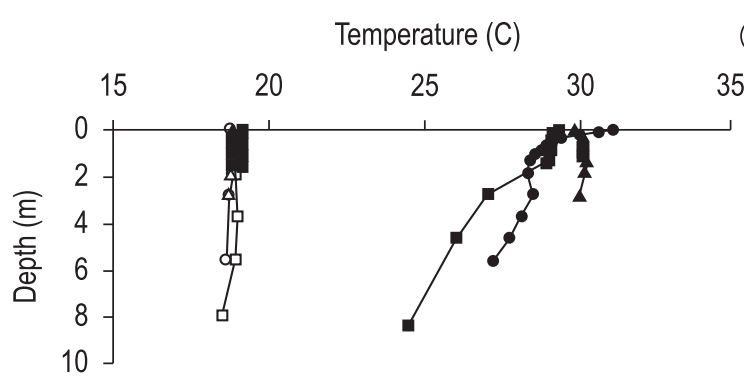

(a)

pH (b)
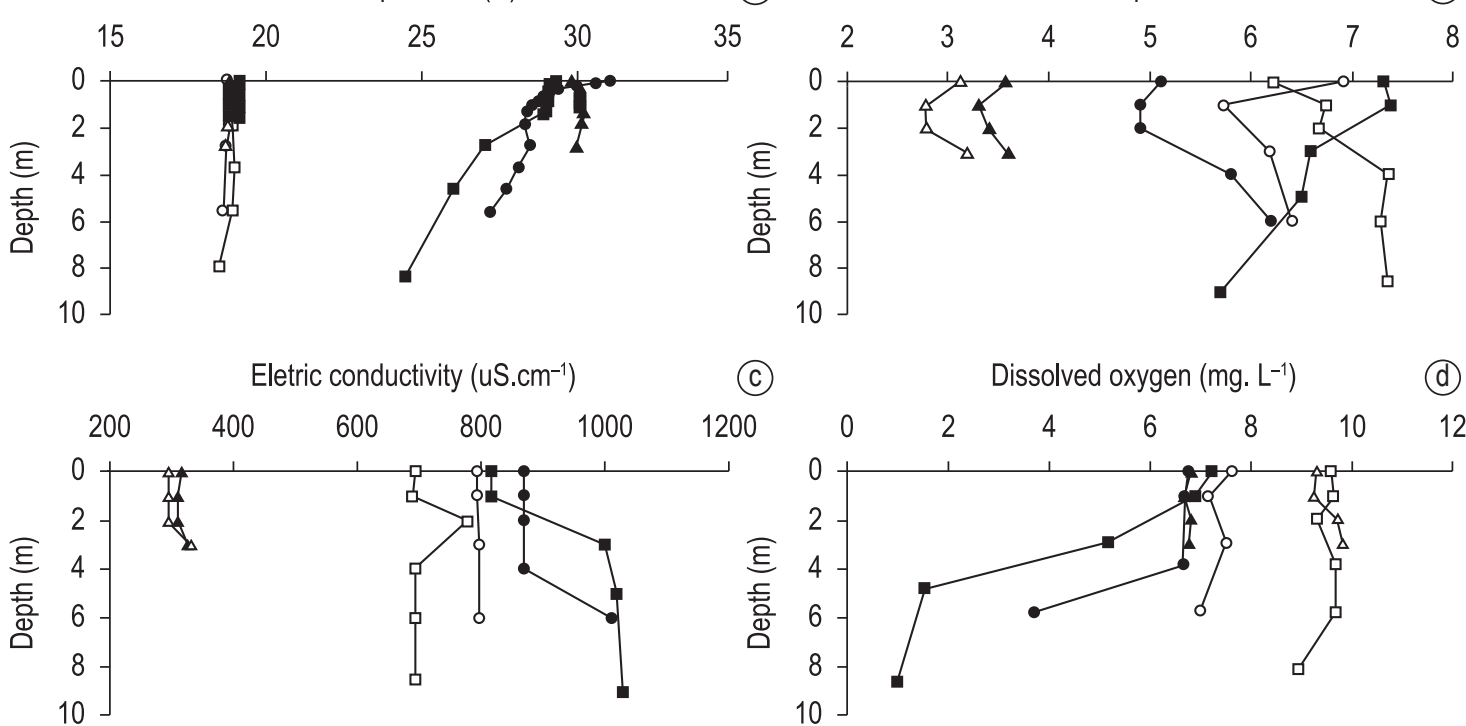

(C)
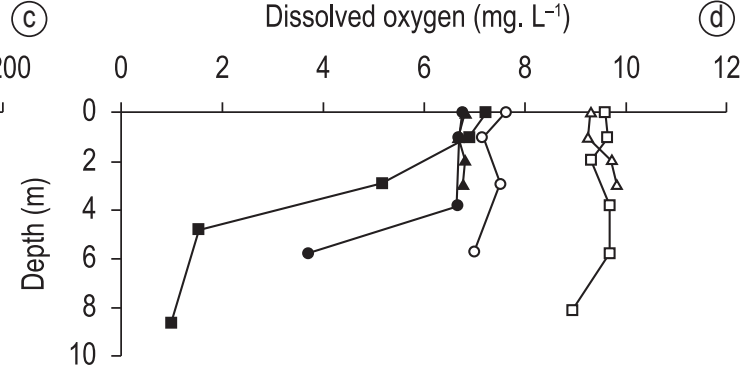

Total solids ( $\mathrm{mg} . \mathrm{L}^{-1}$ )

(e)

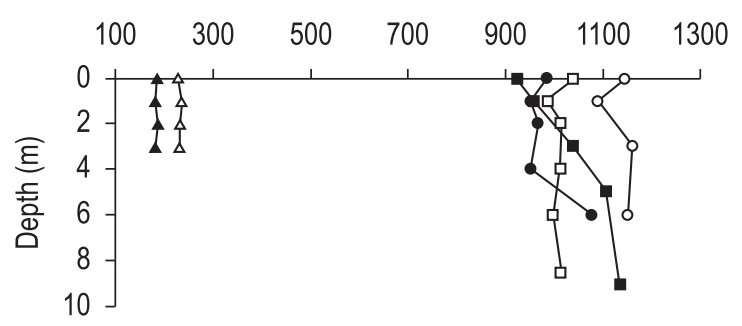

L1-S

L2-S

L3-S $-\square-\mathrm{L} 1-\mathrm{W} \rightarrow-\mathrm{L} 2-\mathrm{W} \rightarrow \triangle \mathrm{L} 3-\mathrm{W}$

Figure 3. Depth profiles of temperature (a), $\mathrm{pH}$ (b), electric conductivity (c), dissolved oxygen (d) and total solids (e) in three lakes (Lake 1 - L1, Lake 2 - L2, Lake 3 - L3) at the Morozini River basin. Summer (S, full) and winter (W, lacked). 
Table 2. Total solids (TS), particulate solids (PS) and dissolved solids (DS) determined in three lakes at the Morozini River basin, in the winter.

\begin{tabular}{ccrrr}
\hline Lake & Depth $(\mathrm{m})$ & TS $\left(\mathrm{mg} . \mathrm{L}^{-1}\right)$ & $\mathrm{PS}\left(\mathrm{mg} . \mathrm{L}^{-1}\right)$ & DS $\left(\mathrm{mg} . \mathrm{L}^{-1}\right)$ \\
\hline & 0.0 & $1,038.0$ & 1.71 & $1,036.3$ \\
& 1.0 & 982.5 & 1.85 & 980.6 \\
1 & 2.0 & $1,011.5$ & 1.71 & $1,009.8$ \\
& 4.0 & $1,008.5$ & 1.28 & $1,007.2$ \\
& 6.0 & 996.5 & 1.14 & 995.4 \\
& 8.5 & $1,012.5$ & 0.71 & $1,011.8$ \\
\hline \multirow{2}{*}{2} & 0.0 & $1,145.0$ & 3.14 & $1,141.9$ \\
& 1.0 & $1,091.5$ & 2.71 & $1,088.8$ \\
& 3.0 & $1,161.5$ & 2.57 & $1,158.9$ \\
& 6.0 & $1,151.0$ & 2.57 & $1,148.4$ \\
\hline \multirow{2}{*}{3} & 0.0 & 227.0 & 0.71 & 226.3 \\
& 1.0 & 234.0 & 1.00 & 233.0 \\
& 2.0 & 231.0 & 1.00 & 231.0 \\
& 3.0 & 230.5 & 2.28 & 228.2 \\
\hline
\end{tabular}

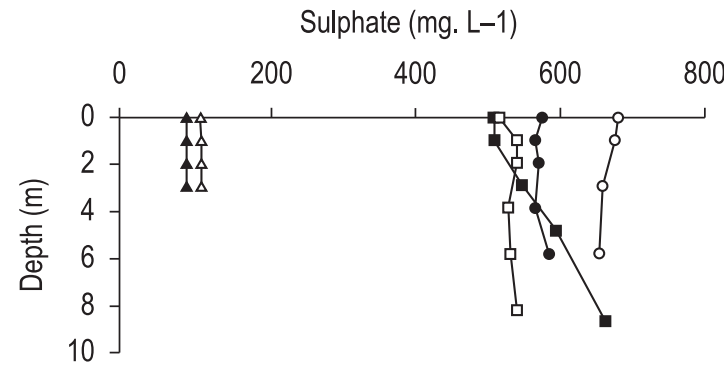

(a) Calcium (mg. L-1)

(b)

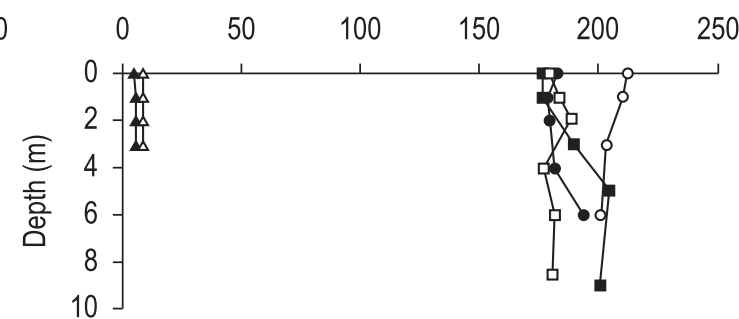

Magnesium (mg. L-1)

(C)

Sodium (mg. L-1)

(d)
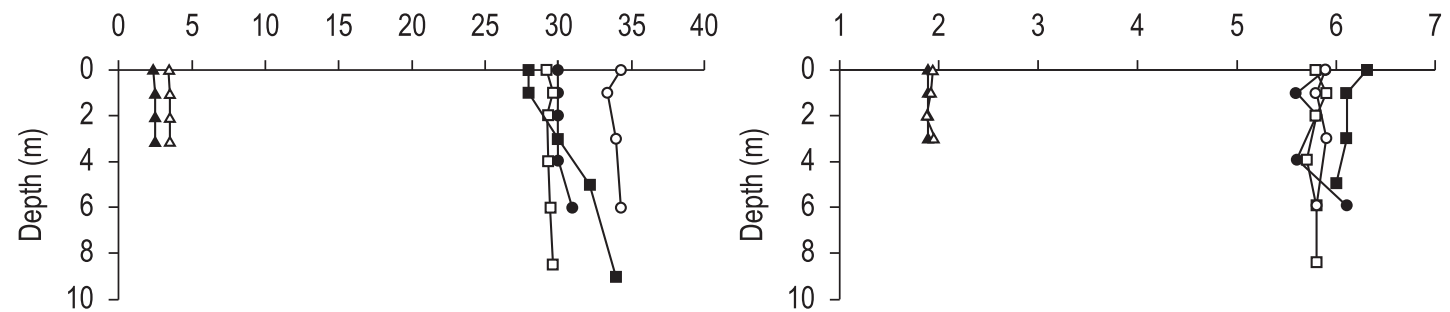

Potassium (mg. L-1)

(e) Aluminium (mg. L-1)

(f)
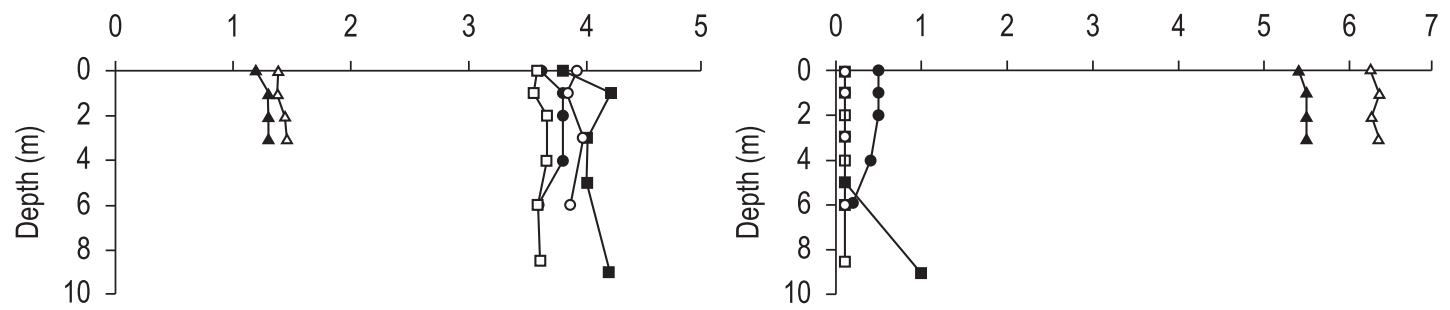

\section{L1-S $\rightarrow$ L2-S $\rightarrow$ L3-S $-\square-\mathrm{L} 1-\mathrm{W} \rightarrow-\mathrm{L}$ L2-W $\rightarrow-$ L3-W}

Figure 4. Concentration of sulfate (a), $\mathrm{Ca}(\mathrm{b}), \mathrm{Mg}$ (c), $\mathrm{Na}$ (d), $\mathrm{K}$ (e) e Al (f) in three lakes (Lake 1 - L1, Lake 2 - L2, Lake 3 - L3) at the Morozini River basin. Summer (S, full) and winter (W, lacked). 
Lakes 1 and 2, respectively (Figure 4d-e). In Lake 3 , the $\mathrm{Na}$ and $\mathrm{K}$ concentrations ranged from 1.2 to $1.9 \mathrm{mg} . \mathrm{L}^{-1}$. Aluminium concentration for Lakes 1 and 2 ranged from 0.1 to $1.0 \mathrm{mg} . \mathrm{L}^{-1}$ while Lake 3 showed higher concentrations, ranging from 5.4 to $6.4 \mathrm{mg} . \mathrm{L}^{-1}$ (Figure 4f).

Silicon concentr ation ranged from 8.1 to $11.0 \mathrm{mg} . \mathrm{L}^{-1}$ in all lakes and study periods (Figure 5a). Low $\mathrm{Fe}$ concentrations were observed in Lake 1 during the winter $\left(0.05\right.$ to $\left.0.15 \mathrm{mg} . \mathrm{L}^{-1}\right)$. Generally the values ranged from 0.30 to $1.28 \mathrm{mg} . \mathrm{L}^{-1}$, except in Lake 1, where during the summer values were 2.5, 6.0 and $11.0 \mathrm{mg} . \mathrm{L}^{-1}$ at depths of 3.0, 5.0 and $9.0 \mathrm{~m}$, respectively (Figure $5 \mathrm{~b}$ ). $\mathrm{Zn}$ concentration varied from $0.045 \mathrm{mg} . \mathrm{L}^{-1}$ to $0.14 \mathrm{mg} . \mathrm{L}^{-1}$ (Figure 5e), and the $\mathrm{Mn}$ concentration ranged from 0.97 to $9.9 \mathrm{mg} . \mathrm{L}^{-1}$ (Figure $5 \mathrm{~d}$ ). Ni concentration ranged from $<0.02$ to $0.07 \mathrm{mg}$. $\mathrm{L}^{-1}$ in summer and $<0.05$ to $0.36 \mathrm{mg} . \mathrm{L}^{-1}$ in winter (Figure $5 \mathrm{e}$ ). In both, winter and summer, $\mathrm{Sr}$ concentration was lower in Lake 3
(0.03 mg. $\left.\mathrm{L}^{-1}\right)$ and higher in Lakes 1 and 2 (0.42$0.51 \mathrm{mg} . \mathrm{L}^{-1}$, respectively) (Figure $5 \mathrm{f}$ ).

B concentration ranged from 0.01 to $0.07 \mathrm{mg} . \mathrm{L}^{-1}$ in the three lakes and in both periods (Figure 6a), and $\mathrm{Ba}$ concentrations were below 0.04 mg.L $L^{-1}$ (Figure 6b).

The following elements were in concentrations below the detection limit of the method: Cd $\left(<0.002 \mathrm{mg} . \mathrm{L}^{-1}\right), \mathrm{Cr}\left(<0.004 \mathrm{mg} . \mathrm{L}^{-1}\right)$, $\mathrm{Pb}\left(<0.05 \mathrm{mg} \cdot \mathrm{L}^{-1}\right), \mathrm{P}\left(<0.2 \mathrm{mg} \cdot \mathrm{L}^{-1}\right)$, and $\mathrm{Cu}$ $\left(<0.02 \mathrm{mg} . \mathrm{L}^{-1}\right)$.

Orthophosphate concentrations were low, less than $10 \mu \mathrm{g} . \mathrm{L}^{-1}$. The reactive silicate concentrations ranged from 1.1 to $9.7 \mathrm{mg} . \mathrm{L}^{-1}$ (Table 3 ).

The first two axes from the principal components analysis account for $74 \%$ of the original matrix total variance. The first and the second axis accounted for 44 and 30\% respectively (Figure 7). The highest factor loadings on the first axis consisted of $\mathrm{pH}$, $\mathrm{Ca}$, TS and $\mathrm{EC}$ in opposition to $\mathrm{Al}$ concentration.

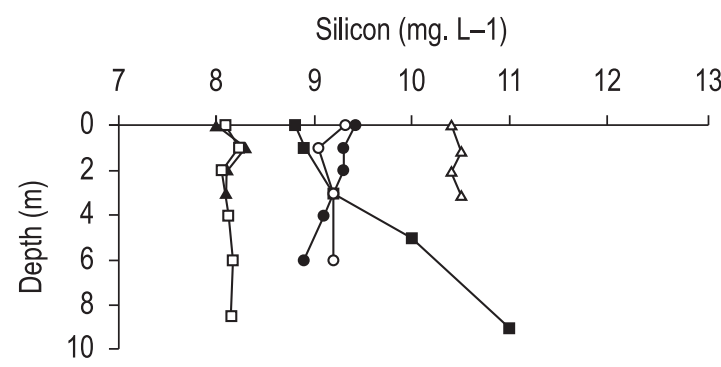

(a)
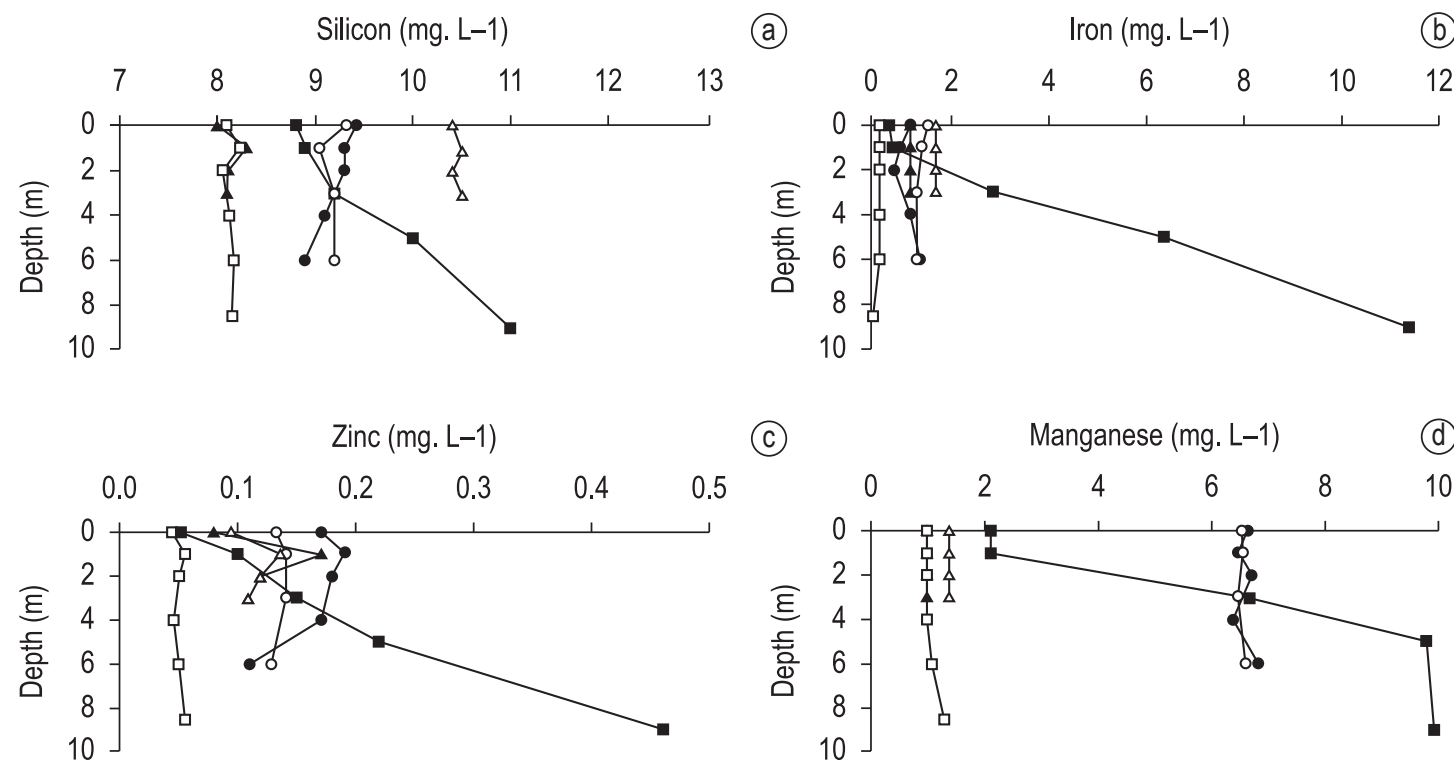

(C)
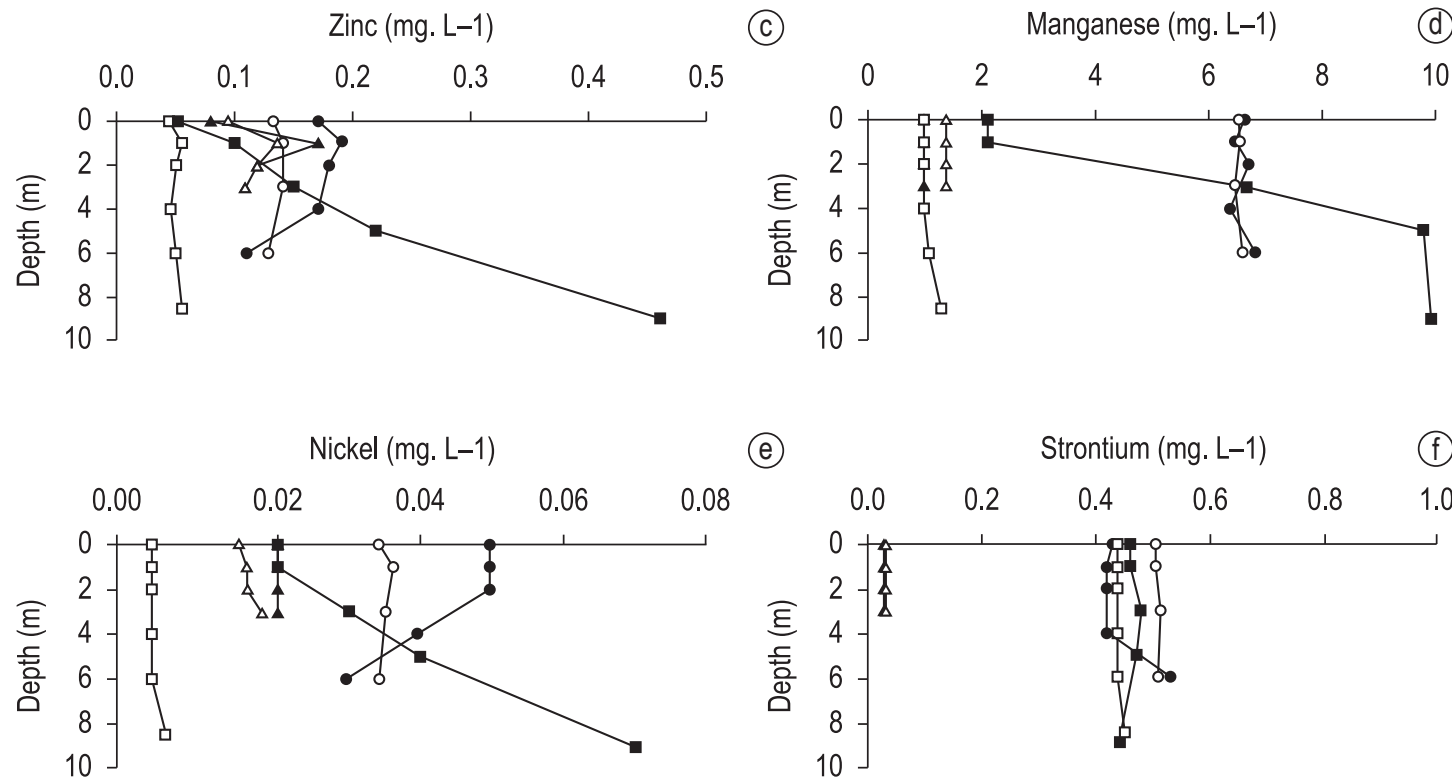

(e)

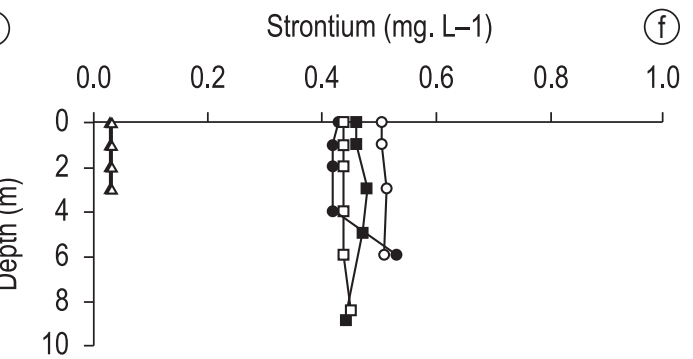

$$
\text { L1-S ๑ L2-S } \rightarrow \text { L3-S } \neg-\text { L1-W }-0-\text { L2-W } \rightarrow-\text { L3-W }
$$

Figure 5. Concentration of $\mathrm{Si}(\mathrm{a}), \mathrm{Fe}(\mathrm{b}), \mathrm{Zn}(\mathrm{c}), \mathrm{Mn}(\mathrm{d}), \mathrm{Ni}$ (e) and $\mathrm{Sc}$ in three lakes (Lake 1 - L1, Lake 2 - L2, Lake 3 - L3) at the Morozini River basin. Summer (S, full) and winter (W, lacked). 


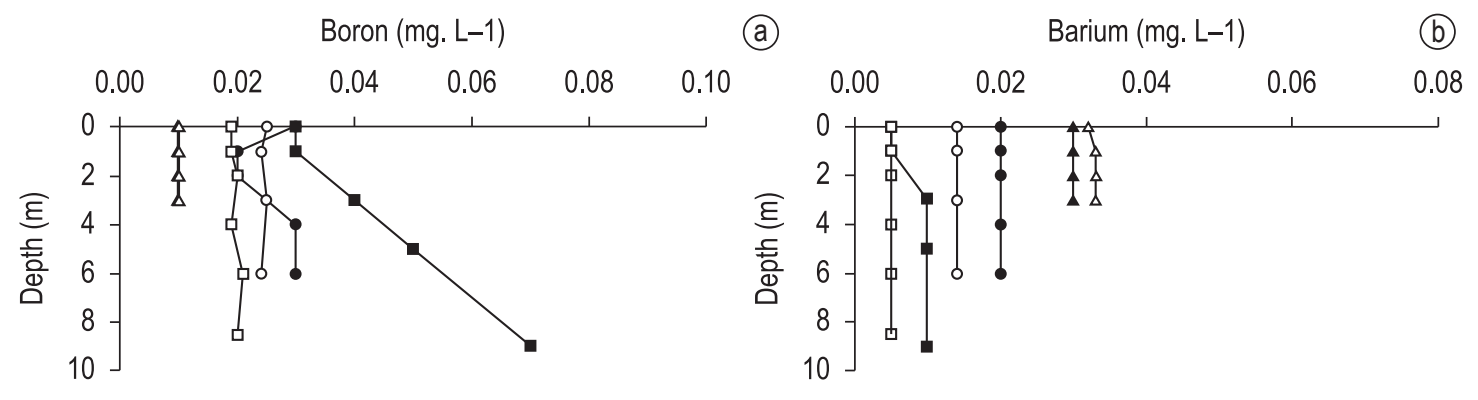

L1-S $\bullet-$ L2-S $\rightarrow$ L3-S $-\square-$ L1-W $-0-$ L2-W $\rightarrow-$ L3-W

Figure 6. Concentration of B (a) e Ba (b) in three lakes (Lake 1 - L1, Lake 2 - L2, Lake 3 - L3) at the Morozini River basin. Summer (S, full) and winter (W, lacked).

Table 3. Depth profiles the $\mathrm{P}_{-} \mathrm{PO}_{4}^{3-}$ and $\mathrm{S}-\mathrm{SIO}_{2}$ in the Summer $(\mathrm{S})$ and Winter (W) in three lakes at the Morozini River basin.

\begin{tabular}{|c|c|c|c|c|c|}
\hline \multirow[t]{2}{*}{ Lake } & \multirow{2}{*}{$\begin{array}{l}\text { Depth } \\
(\mathrm{m})\end{array}$} & $\mathrm{P}-\mathrm{PO}_{4}^{-3}\left(\mu \mathrm{g} \cdot \mathrm{L}^{-1}\right)$ & $\mathrm{S}-\mathrm{SIO}_{2}\left(\mathrm{mg}^{-\mathrm{L}^{-1}}\right)$ & $\mathrm{P}-\mathrm{PO}_{4}^{-3}\left(\mu \mathrm{g} \cdot \mathrm{L}^{-1}\right)$ & $\mathrm{S}-\mathrm{SIO}_{2}\left(\mathrm{mg}^{\mathrm{L}} \mathrm{L}^{-1}\right)$ \\
\hline & & S & S & W & W \\
\hline \multirow[t]{8}{*}{1} & 0.0 & $<10$ & 8.15 & $<10$ & 8.03 \\
\hline & 1.0 & $<10$ & 8.34 & $<10$ & 7.95 \\
\hline & 2.0 & & & & 7.43 \\
\hline & 3.0 & $<10$ & 8.41 & $<10$ & \\
\hline & 4.0 & & & & 7.80 \\
\hline & 5.0 & $<10$ & 1.96 & $<10$ & \\
\hline & 6.0 & & & & 7.80 \\
\hline & 9.0 & $<10$ & 9.70 & $<10$ & 7.72 \\
\hline \multirow[t]{6}{*}{2} & 0.0 & $<10$ & 8.18 & $<10$ & 8.16 \\
\hline & 1.0 & $<10$ & 8.22 & $<10$ & 1.10 \\
\hline & 2.0 & $<10$ & 8.05 & & \\
\hline & 3.0 & & & $<10$ & 8.21 \\
\hline & 4.0 & $<10$ & 8.24 & $<10$ & \\
\hline & 6.0 & $<10$ & 7.95 & $<10$ & 8.04 \\
\hline \multirow[t]{4}{*}{3} & 0.0 & $<10$ & 7.37 & $<10$ & 8.45 \\
\hline & 1.0 & $<10$ & 7.28 & $<10$ & 8.55 \\
\hline & 2.0 & $<10$ & 7.51 & $<10$ & 8.56 \\
\hline & 3.0 & $<10$ & 7.29 & $<10$ & 9.29 \\
\hline
\end{tabular}

Relevant factor loadings for the second axis were $\mathrm{Zn}, \mathrm{Fe}$ and $\mathrm{Si}$ in opposition (negatively correlated) with $\mathrm{pH}$ and dissolved oxygen. A space effect was observed with Lake 3 apart from Lakes 1 and 2. Lake 3 presented higher $\mathrm{Al}$ concentration and lower $\mathrm{Ca}$, $\mathrm{pH}$ and $\mathrm{EC}$ values in both studied periods. Despite lakes 1 and 2 presented small differences for the same season, the biggest differences observed for theses lakes were observed between the sampling periods (summer and winter).

\section{Discussion}

Water column was thermally homogeneous in all the lakes in winter. In summer, Lakes 1 and 2 showed micro stratifications, whereas Lake 3 was thermally homogeneous. This fact is probably due to depth differences between the lakes combined with the effect of the wind and also it can be related to the air temperature seasonal pattern observed in the region. Therefore, the differences observed between winter and summer for Lakes 1 and 2 could be explained by the marked pattern of temperature observed along the year in the study region (Figure 7). For Lake 3, the similarity among sampling periods, probably, is associated with the low depth, allowing wind action and constant water column mix.

The profiles of DO that were measured in the lakes also corroborated the hypothesis of chemical stratification in Lakes 1 and 2 and homogeneity in 


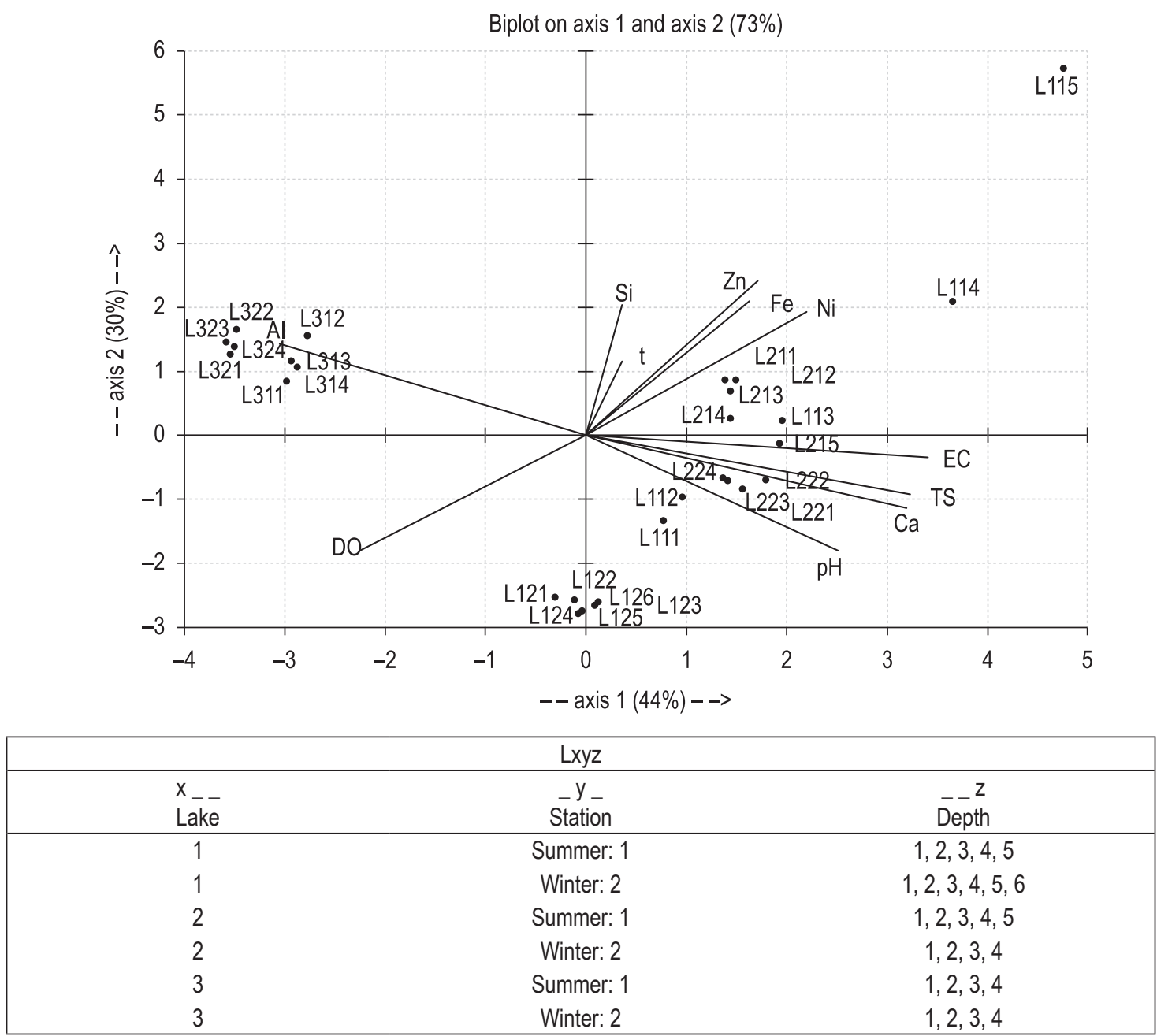

Figure 7. PCA of the three lakes studied in the Morozini River Basin. t: temperature; TS: total solids; Ca: Calcium; Al: Aluminium; Si: Silicon; Fe: Iron; Zn: Zinc; Ni: Nickel; pH; EC: electric conductivity; DO: dissolved oxygen. L111: it means, Lake 1, at summer (1) and to first depth (1), respectively for three lakes like shown in the following table:

Lake 3, in this case, like observed in two sampling periods. Low DO concentration in the deepest parts of Lake 1 in the summer is probably due to the consumption of oxygen in oxidation of pyrite, a process that results in dissolution of certain ions and metals such as $\mathrm{SO}_{4}^{-2}, \mathrm{Fe}, \mathrm{Mn}, \mathrm{Zn}$ and $\mathrm{Ni}$ (Blunden et al., 2001).

Data obtained in the winter showed that most of the solid fraction in all three lakes is in dissolved form, $\mathrm{SO}_{4}^{-2}$ and $\mathrm{Ca}$, mainly, and that the particulate matter accounts for only a small part of the TS.

The high EC values for Lakes 1 and 2 are probably due to the high ion concentration, especially $\mathrm{SO}_{4}^{-2}$ (above $500 \mathrm{mg} . \mathrm{L}^{-1}$ ) and $\mathrm{Ca}$ (higher than $\left.180 \mathrm{mg} . \mathrm{L}^{-1}\right)$ that also contribute to high TS values. In Lake 3, the lowest values of EC may be a consequence of the lower concentration of $\mathrm{SO}_{4}^{-2}$, $\mathrm{Ca}, \mathrm{Mg}, \mathrm{Na}$ and $\mathrm{K}$.

CSN Company is responsible for coal mining in this region and it is also in charge of the recovery of affected lakes. In the past $\mathrm{Ca}(\mathrm{OH})_{2}$ was added to the Lakes 1 and 2 in order to increase their $\mathrm{pH}$. However, $\mathrm{SO}_{4}^{-2}, \mathrm{Ca}, \mathrm{Mg}$ and $\mathrm{Fe}$ concentration remained high. In appropriate concentrations, these ions are important for the metabolism of various organisms, but they can cause toxic effects at higher concentrations. It is important to emphasize that water neutralization does not directly affect the causes of the acidity. Additionally, water neutralization can increase turbidity, which becomes then a new environmental problem.

The high concentration of $\mathrm{SO}_{4}^{-2}$ and $\mathrm{Ca}$ in Lakes 1 and 2 can be explained by the addition of 
$\mathrm{Ca}(\mathrm{OH})_{2}$, which increases the water solubility of these ions. A high $\mathrm{SO}_{4}^{-2}$ concentration was found by Silvano and Raya-Rodriguez (2003) in Lagoa Azul, a lake located close to the site of this study, in the coal-producing basin of Siderópolis city. These authors attributed this condition to the oxidation of pyrite from coal mining.

Data of $\mathrm{pH}, \mathrm{EC}, \mathrm{TS}, \mathrm{SO}_{4}^{-2}, \mathrm{Ca} \mathrm{Mg}, \mathrm{Na}, \mathrm{K}$, $\mathrm{Al}$, and $\mathrm{Sr}$, mainly in the Lake 3, indicate that coal mining has made a strong environmental impact. Lakes 1 and 2 discriminated from Lake 3 , mainly because the last was strongly affected by the coal mining, due a CSN intervention with the addition of $\mathrm{Ca}(\mathrm{OH})_{2}$. However, all three lakes remain exposed to high pyrite content and are, consequently, highly affected by the coal mining process.

Previous studies carried out in the basins of Rivers Conde, Ratos and Porteira (Rio Grande do Sul state, Brazil) registered mean $\mathrm{pH}$ values of about 6.0. Extreme values of 2.6 and 2.7 were found in some locations probably due to the impact of mining on the drainage basin. Low $\mathrm{pH}$ values in areas where coal mining takes place are often due to nearby pyrite deposits (Zanardi Junior and Porto, 1991).

The highest aluminium concentrations observed in Lake 3 are probably due to the lower $\mathrm{pH}$ values, which increase $\mathrm{Al}$ solubility. The concentration of $\mathrm{Al}$ in freshwater around the world varies according to $\mathrm{pH}$ values. Al concentrations are higher when $\mathrm{pH}$ is low (Siegfried et al., 1989). In the Pantano Lake, a $\mathrm{pH}$ of around 3.9 was associated with $\mathrm{Al}$ concentrations of 0.1 to $3.7 \mathrm{mg} . \mathrm{L}^{-1}$ (Courtijn et al., 1987 apud Azevedo and Chasin, 2003). Lake Shield (Ontario and Quebec, Canada) showed $\mathrm{pH}$ values ranging from 4.4 to 7.1 and $\mathrm{Al}$ concentrations ranging from 0.05 to $0.37 \mathrm{mg}$. $\mathrm{L}^{-1}$. Lake Ipê (Parana State, Brazil), an area relatively untouched by mankind, has low $\mathrm{Al}$ concentrations ranging from 8 to $21 \mu \mathrm{g} . \mathrm{L}^{-1}$ (Barreto et al., 2005). In this study, $\mathrm{Al}$ concentrations are higher than those mentioned above.

Similar $\mathrm{SO}_{4}^{-2}, \mathrm{Fe}, \mathrm{Al}$ and $\mathrm{Mg}$ concentrations found in Morozini River lakes also were found in lakes of the Fiorita River basin (Siderópolis City, Santa Catarina State, Brazil) (Pompêo et al., 2004). These lakes in Fiorita River basin also are located in abandoned coal mining area, explored with the same procedures practiced in the Morozini River.

In a previous study in the lakes located in Morozini River basin, Waterloo (2002) stated that the lakes were used as dumps for coal mining waste, and the waste was considered responsible for the properties of surface and subterranean water in the Morozini mining field. The results of Waterloo (op cit.) are similar to those found in this study. However, our study found much lower $\mathrm{pH}$ values, which can be partly explained by the addition of $\mathrm{Ca}(\mathrm{OH})_{2}$ in Lakes 1 and 2 after Waterloo's study.

The most extreme changes in water quality found by Waterloo (2002) were for the subterranean water ( $\mathrm{pH}$ approximately 4.0; sulfate $>1000 \mathrm{mg} . \mathrm{L}^{-1}$, $\left.\mathrm{Fe}>100 \mathrm{mg} \cdot \mathrm{L}^{-1}\right)$. This author concludes that the higher $\mathrm{pH}$ values are due to the flow of oxidized $\mathrm{SO}_{4}^{-2}$ from the pyrite in the mining debris and also as a by-product of secondary reactions involving $\mathrm{Fe}$ in anaerobic conditions.

The Brazilian legislation, in accordance with CONAMA Resolution 357 (Brasil, 2005), classifies water quality in order to assess the environmental quality of lakes and ponds. The CONAMA Resolution also defines proper water use, according to the biological, chemical and physical characteristics of each class. Five freshwater classes have been defined for typical use and human consumption. The Special Class, represent the water crud used in the water supply after disinfection (more restrictive use), and the Class 1 to 4 . Class 4 is to use less restrictive, such as navigation and harmonious landscape.

The lakes in our study had a range of chemical and physical characteristics, which show that the water quality was seriously affected. For some variables, these lakes failed to meet the necessary criteria for classification standards (Table 4). Based on the values found in the superficial water, the Lakes

Table 4. Water body conformity of the Lakes 1, 2 and 3 in relation to CONAMA Resolution 357 (Brasil, 2005).

\begin{tabular}{llll}
\hline \multicolumn{1}{c}{ Variable } & \multicolumn{3}{c}{ Lake } \\
\cline { 2 - 4 } & 1 & 2 & 3 \\
\hline Dissolved oxygen & 4 & 4 & 1 \\
$\mathrm{pH}$ & $*$ & $*$ & $*$ \\
Total dissolved solids & 4 & 4 & 3 \\
Sulfate & 4 & 4 & 3 \\
Dissolved iron & 3 & 3 & 3 \\
Aluminium & 4 & 4 & 4 \\
Zinc & 1 & 1 & 1 \\
Manganese & 4 & 4 & 4 \\
Boron & 1 & 1 & 1 \\
Barium & 1 & 1 & 1 \\
Nickel & 1 & 2 & 1 \\
Recommendation & 4 & 4 & 3 \\
\hline$*$ Outside
\end{tabular}

* Outside the limits for any of the established classes. 
1 and 2 are in accordance to Class 4, and the Lake 3 in Class 3, according to CONAMA Resolution. According to our suggested classification, Lakes 1 and 2 should have their uses strictly limited to navigation and landscaping (Class 4) and Lake 3 should only supply water for human consumption after conventional or advanced treatment (Class 3).

\section{Conclusions}

Coal mining activity and waste disposal practices adopted by the mining companies in the Morozini River basin, has drastically affected the water quality of the examined water bodies and left them inappropriate for human use apart from landscaping. Immediate intervention is necessary because the local population uses the lakes for leisure, swimming and fishing.

\section{Acknowledgements}

This research was supported by $\mathrm{CNPq}$ (proc. 476080/01-1).

\section{References}

American Public Health Association - APHA. 1985. Standard methods for the examination of water and wastewater. Washington: APHA.

ASTA, MP., CAMA, J., SOLER, JM., ARVIDSON, RS. and LÜTTGE, A. 2008. Interferometric study of pyrite surface reactivity in acidic conditions. American Mineralogist, vol. 93, p. 508-519. http:// dx.doi.org/10.2138/am.2008.2685

AZEVEDO, FA. and CHASIN, AAM. 2003. Metais: gerenciamento da toxicidade. São Paulo: Atheneu.

BARRETO, WJ., RECHE RIBEIRO, M., SCARMINIO, S., SOLCI, MC., NOZAKI, J., OLIVEIRA, E. and GIANCOLI, SR. 2005. Determination of trace metal concentration in a flooded tropical lake during a complete hydrological cycle. Annales de Limnologie, International Journal of Limnology, vol. 41, no. 1, p. 47-55. http://dx.doi.org/10.1051/limn/2005005

BLUNDEN, B. and INDRARATNA, B. 2001. Pyrite oxidation model for assessing ground-water management strategies in acid sulfate soils. Faculty of Engineering, University of Wollongong. 13 p. Available from: <http://ro.uow.edu.au/engpapers/181>. Access in: mar. 2011.

Brasil. Ministério do Meio Ambiente. Conselho Nacional do Meio Ambiente - CONAMA. Resolução no 357, de 17 de março de 2005. Dispóe sobre a classificação dos corpos de água e diretrizes ambientais para o seu enquadramento, bem como estabelece as condições e padrốes de lançamento de efluentes, e dá outras providências. Diário Oficial da República Federativa do Brasil, Brasília, DF, 18 mar. 2005. 23 p.

GOLTERMAM, HL., CLYMO, RS. and OHNSTAD, MAM. 1978. Methods for physical and chemical analysis of freshwater. 2th ed. Oxford: Blackwell Scientific Publications.

Japan International Cooperation Agency - JICA. 1995. The feasibility study on recuperation of mined out areas in South region of Santa Catarina State, the Federation Republic of Brasil. Mitsubishi Materials Corporation, Chiyoda-Dames \& Moore Co., Ltd. 397 p.

KOPEZINSKI, I. 2000. Mineração X Meio Ambiente: consideraçôes legais, principais impactos ambientais e seus processos modificadores. Porto Alegre: Editora Universidade.

LEGENDRE, P. and LEGENDRE, L. 2003. Numerical ecology. 2th ed. Amsterdam: Elsevier Science.

MCALLISTER, ML. and MILIOLI, G. 2000. Mining sustainable: opportunities for Canada and Brazil. Mineral \& Energy, vol. 15, no. 2, p. 3-14.

MILIOLI, G. 1999. Abordagem ecossistêmica para a mineração: uma perspectiva comparativa para Brasil e Canadá. Florianópolis: Universidade Federal de Santa Catarina. 410 p. [Tese de Doutorado em Engenharia de Produção].

POMPÊO, MLM., MOSCHINI-CARLOS, V., ALEXANDRE, NZ. and SANTO, E. 2004. Qualidade da água em regiáo alterada pela mineração de carvão, Microbacia do Rio Fiorita (Siderópolis, SC, Brasil). Acta Scientenarium, vol. 26, no. 2, p. 125-136.

ROSE, AW. and CRAVOTTA, CA. 1998. Geochemistry of coal mine drainage. In BRADY, BC., KANIA, T., SMITH, WM. And HORNBERGER, RJ., eds. Coal Mine Drainage Prediction and Pollution Prevention in Pennsylvania. Pennsylvania Department of Environmental Protection. p. 1.1-1.22.

SIEGFRIED, CA., BLOOMFIELD, JA. and SUTHERLAND, JW. 1989. Acidity status and phytoplankton species richness, standing crop, and community composition in Adirondack, New York, U.S.A. lakes. Hydrobiologia, vol. 175, no. 1, p. 13-32.

SILVANO, J. and RAYA-RODRIGUEZ, MT. 2003. Evaluation of metals in water, sediment and fish of Azul lake, an open-air originally coalmine (Siderópolis, Santa Catarina State, Brazil). Acta Limnologica Brasiliensia, vol. 15, no. 3, p. 71-80.

STRICKLAND, JD. and PARSONS, TR. 1960. A manual of seawater analysis. Bulletin of Fisheries Research Board of Canada, vol. 125.

SÔNEGO, M., BACK, AJ. and VIEIRA, J. Estaçōes meteorológicas do municipio de Criciúma: Monitoramento de dados meteorológicos para 
prevençáo de enchentes e deslizamentos. Available from: <http://www.ciram.com.br/siscrici/>. Access in: mar. 2011.

Waterloo Brasil. 2002. Avaliação hidrogeológica e modelagem matemática. Waterloo Hydrogeologic, Inc. Relatório.
ZANARDI JUNIOR, V. and PORTO, ML. 1991. Avaliação do sistema de lagoas em área de mineração de carvão a céu aberto: metais pesados na água, plantas e substrato. Boletim do Instituto de Biociências, vol. 49 , p. 1-83.

Received: 22 October 2010 Accepted: 20 December 2011 